UDC 378:81'243:004:159.942.5-026.565(076)=111

\author{
Olga Trotsenko \\ PhD of Pedagogical Sciences, \\ Associate Professor of English Philology Department of the Faculty of Foreign Languages \\ Vasyl Stefanyk Precarpathian National University, Ivano-Frankivsk, Ukraine \\ ORCID ID 0000-0002-5023-0563 \\ trocolya@gmail.com \\ Olha Bilyk \\ $\mathrm{PhD}$ of Philological Sciences, \\ Associate Professor of English Philology Department of the Faculty of Foreign Languages \\ Vasyl Stefanyk Precarpathian National University, Ivano-Frankivsk, Ukraine \\ ORCID ID 0000-0002-3973-0700 \\ noiproks2014@ukr.net \\ Nataliia Pyliachyk \\ PhD of Philological Sciences, \\ Associate Professor of English Philology Department of the Faculty of Foreign Languages \\ Vasyl Stefanyk Precarpathian National University, Ivano-Frankivsk, Ukraine \\ ORCID ID 0000-0002-0642-6745 \\ natapiliachik@gmail.com
}

\title{
ICT AS A TOOL FOR REDUCING ANXIETY IN PRE-SERVICE FOREIGN LANGUAGE TEACHERS' PRACTICUM
}

\begin{abstract}
Pre-service teachers who have grown up with ICT all around them are considered to be digitally literate. In this case, they are supposed to be proficient in their use of ICT for learning and teaching. This article explores ICT as the factor that influences pre-service teachers' anxiety. Additionally, it aims at determining the role of ICT in reducing the level of pre-service foreign language teachers' anxiety during their teaching activities. Anxiety is considered to have a powerful impact on people's everyday life and on learning and teaching process in particular.The research tools were close-ended questionnaires filled by the respondents. The first one was used to measure pre-service teachers' anxiety scale in different everyday life situations. The second questionnaire was based on the authors' socio-psychological experiment, aiming at revealing the influence of ICT on pre-service teachers' anxiety during their teaching practicum. The study was carried out with 120 pre-service EFL teachers studying at Vasyl Stefanyk Precarpathian National University and Pavlo Tychyna Uman State Pedagogical University who completed their teaching practicum as part of their graduation requirement at the Departments of Foreign Languages. The data obtained from the questionnaires were grouped into two main categories: the general level of students' anxiety and the anxiety connected with using ICT in teaching English. The latter was categorized into "Very positive", "Positive" and "Negative" groups based on pre-service teachers' experience gained during their teaching practicum. ICT use was found to be positively and significantly related to reducing teachers' level of anxiety. The results of the research proved that the students who did the ICT-related course as a part of their curriculum felt more confident while conducting classes and their level of anxiety was reduced while using modern information technologies.
\end{abstract}

Keywords: ICT; pre-service teachers; reducing anxiety; teaching practicum.

\section{INTRODUCTION}

Teaching has always been one of the most challenging processes as teachers often face anxiety-provoking problems. The most common ones for a foreign language teacher are as follows: teaching English through English, being asked unexpected questions, lack of students' motivation, poor classroom management skills, undergoing peer observation, teaching language skills, using a new teaching technique, using the time effectively, teaching 
a new/different level, using a new/different device, etc. One of the reasons why foreign language teachers experience such difficulties is anxiety.

According to Longman Dictionary of Contemporary English anxiety is "the feeling of being very worried about something" $[1, \mathrm{p} .55]$ and it can be defined as "a state of uneasiness and apprehension or fear caused by the anticipation of something negative" [2]. Furthermore, speaking about foreign language pre-service teachers, the notion of foreign language teaching anxiety appears [3], which is understood as a physiological discomfort or apprehension which is unique for people who are responsible for teaching foreign language learners. Foreign language teaching anxiety includes cognitive, affective and socio-cultural factors and can evoke the feeling of hesitating and questioning professional adequacy in teaching and practising foreign languages with real students in a real teaching context. In the study carried out by Horwitz and Cope [4] foreign language teaching anxiety (FLTA) is a distinct complex of self-perceptions, beliefs, feelings, and behaviours related to classroom language teaching that arises from the uniqueness of the language teaching process.Moreover, it is imperative that language teachers should be sensitive to foreign language teaching anxiety in their classes so as to create psychologically sound atmosphere.

The problem statement. Since information and communication technologies (ICTs) have become an essential part of education process, language teachers of the $21^{\text {st }}$ century face the necessity to facilitate rather than just to provide knowledge to learners. Hence, teachers tend to use modern technologies not only as 'presentation tools' but also as 'supportive tools' [5]. From this perspective, the use of ICT can be regarded as one of the most effective and flexible ways for professional development of pre-service teachers. When ICTs were introduced into workplaces, schools in particular, computers were a source of real anxiety for teachers who were concerned with using them in class, specifically learning to use them and dealing with their failures [6].

Some researchers have revealed the fact that teachers experience computer anxiety, which is understood as unpleasant psychological activation and discomfort due to the current or future use of ICT and which is considered one of the components of stress [7]. Computer anxiety can be defined as the teachers' feeling of discomfort, apprehension and fear of coping with ICT tools or uneasiness in the expectation of negative outcomes from computer-related operations [8].With the rapid integration of ICT into all branches of education, modern computer technologies lead to a positive attitude toward implementation of ICT into educational process. Moreover, ICT may become a successful tool for reducing not only computer anxiety but also other affective factors during pre-service foreign language teachers' practicum.

Nowadays teaching practicum is an inseparable part of pre-service teachers' education, which enables students to perform the roles of teachers in real classroom. Usually practicum consists of preparing lesson plans, conducting classes and assessing students' work. In most cases such type of activity is stressful for pre-service teachers who feel anxiety during their teaching practicum. A certain amount of anxiety helps learners work more effectively [9] and it can be a positive force for teachers if it is at the right scale [10], but too much anxiety can block teachers' successful performance. The present study was carried out to reveal the way ICTs can reduce pre-service teachers' anxiety and contribute to effective delivery of classes and professional self-development during teaching practicum.

Analysis of recent studies and publications. Within the framework of innovative teaching ICT changes teaching and learning, namely the way teachers teach and students learn. The study [11] revealed the idea that foreign language teachers have come across new challenges due to ever-increasing possibilities of the ICT use in the context of the $21^{\text {st }}$ century school. 
ICT is viewed as a powerful and effective tool for educational reform and change. A number of previous publications have shown that an appropriate use of ICT can raise educational quality and connect learning process to real-life situations [12], [13]. Teaching process based on ICT no longer depends only on printed materials. Modern Internet-resources give a possibility to obtain knowledge through video clips, audio recordings, visual presentations,etc. The research carried out by Sánchez and Alemán revealed that ICT assists in transforming a teaching environment into a learner-centered one [14].

According to the recent study [15], lack of understanding of the capabilities of ICT and absence of computer literacy represent obstacles to using modern technologies in teaching. In the literature there exist many survey-based studies stating that pre-service teachers - or teachers under training - undergo the negative influence of computer anxiety (also called techno-anxiety) [16], [17] causing foreign language teaching anxiety [18]. Such difficulties are not limited only to teachers but to teacher education institutions as well. The research [19] explains that the latter should prepare pre-service teachers to successfully integrate ICT into teaching process. Aguei and Voogt [20] add that these institutions need to combine pedagogical and technology-related issues in pre-service teachers' education, which will enhance their ICT competence and help increase their experience in using technology in their future classes. A key challenge for teacher educators is to provide learning experiences at university that will allow pre-service teachers to apply technological, pedagogical and content knowledge in teaching practicum [21].

The study carried out by Tum [22] focuses on the anxiety experienced by a non-native foreign language student teacher. It is stated that if potential negative influence of anxiety on foreign language teaching is taken into consideration, it is necessary that measures should be taken to provide courses within teacher education programs that would help students lower their level of anxiety prior to the initiation of their teaching careers. Thus, it can be concluded that carefully selected courses can contribute to the pre-service teacher performance during their practicum.

From the review of the literature it is seen that previous studies have focused on foreign language teaching and learning anxiety [23], ICT anxiety [24], ICT in education [25], integrating ICT in pre-service teacher education [26], [27],etc. However, ICT as a tool for reducing anxiety of pre-service teachers has not been considered so far. The unique aspect of this study and the major contribution to the research on foreign language anxiety is that it focuses on the way ICT may help student teachers eliminate or cope with language teaching anxiety during their practicum.

The purpose of the article. The goal of this article is to study the role of ICT in reducing the level of anxiety of pre-service foreign language teachers during their performance in class. The use of ICT by Ukrainian pre-service teachers during their teaching practicum is in the centre of attention. The specific focus is on the educational course 'Information and Communication Technologies (ICT) in Learning and Teaching English' provided for teachers under training.

\section{RESEARCH METHODS}

The aim of the article presupposes the use of some procedures. To find out the answer to the research questions such methods as research design, data collection and data analysis have been used. The study employs a descriptive method as the essential one in scientific research. According to Gay's (1987) understanding of a descriptive method, it is a method of research that involves collecting data to test a hypothesis or to answer questions concerning the current status of the subject of research [28]. In this study we test our hypothesis by conducting a questionnaire designed by Taylor [29] to measure pre-service teachers' anxiety 
scale in various situations. Moreover, the authors' socio-psychological experiment has been conducted to answer questions concerning the influence of ICT on pre-service teachers' anxiety during their teaching practicum.

Participants. Sixty pre-service teachers of the specialty "Secondary Education" (year 4 students) and sixty pre-service teachers of the specialty "Philology" (year 4 students) of the Department of Foreign Languages, Faculty of English Philology (Vasyl Stefanyk Precarpathian National University and Pavlo Tychyna Uman State Pedagogical University) participated in the study. They were enrolled in the teaching practicum as a part of their academic curriculum. This research uses such instruments in the data collection process as two close-ended questionnaires, which were held at the end of teaching practicum. The first one is aimed at manifesting the general level of pre-service teachers' anxiety. The second one deals with their level of anxiety using ICT in class during teaching practicum.

Questionnaire is considered to be the most effective instrument used in the descriptive research for collecting data about the phenomena that are not directly observable such as inner experience, opinions, values, interests, and the like [30]. It aims at getting specific information data gathered from the participants who were asked to fill close-ended questionnaires after their teaching practicum.

To assess pre-service foreign language teachers' anxiety, the Taylor Manifest Anxiety Scale (TMAS) as a test of anxiety as a personality trait designed and validated by Taylor [29] has been used. TMAS is a questionnaire that asks participants to express how anxious they are in various life situations. To collect the data, some steps have been followed. First, the researcher distributed questionnaires to respondents. The sets of those questionnaires were administered after teaching practicum. The participants of both specialties were to rate each item as true or false. It took them four to ten minutes to complete. After filling these questionnaires, the participants handed in their papers for a profound analysis by the researchers.

Second, the researchers sorted out the questionnaires. To avoid the invalid data, the questionnaires in which all the items were not filled in were not taken for analysis. Third, the questionnaire answers were scored. TMAS contains 38 items, each of which is answered "True" or "False". For this research an anxiety score was derived by means of summing the ratings of 38 statements.

To determine the level of pre-service teachers' anxiety while using ICT in class during teaching practicum the respondents were asked to fill in the authors' socio-psychological questionnaire. It consists of two parts: 40 statements to which a "yes" or "no" option is given and the part in which the pre-service teachers were to reflect on the way they felt while using ICT in class during the teaching practicum.

\section{THE RESULTS AND DISCUSSION}

The data collected by the researchers give evidence that sixty students of the specialty "Secondary Education" and the same number of students of the specialty "Philology" have either intermediate or high level of anxiety according to TMAS. Among 120 respondents 82 $(68,3 \%)$ were at intermediate anxiety level and $38(31,7 \%)$ are characterized by a high level of anxiety. It means that all students are anxious in general and consequently, this fact influences their anxiety level during teaching practicum.

The second questionnaire has been designed by the authors of the article. It is a sociopsychological experiment which aims at manifesting pre-service foreign language teachers' anxiety scale while using ICT during their teaching practicum, taking into consideration the difference between the syllabi of two specialties - "Secondary Education"and "Philology". The percentage of the data concerning the anxiety of students of the two specialties under 
study was determined and the related table was created. In other words, the data were compared (both in numbers and percentage), which is discussed further.

Table 1

\section{Level of anxiety using ICT}

\begin{tabular}{|l|c|c|c|c|c|c|}
\hline \multirow{2}{*}{ Specialty } & \multicolumn{2}{|c|}{ Low } & \multicolumn{2}{c|}{ Intermediate } & \multicolumn{2}{c|}{ High } \\
\cline { 2 - 7 } & $\%$ & $\mathrm{n}$ & $\%$ & $\mathrm{n}$ & $\%$ & $\mathrm{n}$ \\
\hline $\begin{array}{l}\text { Secondary } \\
\text { Education }\end{array}$ & $61,7 \%$ & 37 & $35 \%$ & 21 & $3,3 \%$ & 2 \\
\hline English Philology & $23,3 \%$ & 14 & $68,3 \%$ & 41 & $8,4 \%$ & 5 \\
\hline
\end{tabular}

As this study deals with exploring the level of pre-service teachers' anxiety using ICT, the respondents were asked to express their opinion on using ICT during their practicum at school. To effectively analyse the personal opinion of each student, the following task was given to them: "Explain your attitude to using ICT in classes during your teaching practicum at school (write NO MORE THAN 5 SENTENCES using such phrases as I FEEL CONFIDENT/SATISFIED; I FEEL WORRIED/NERVOUS or your own ideas)". The reflections collected from each student were analysed individually and were classified into three groups, namely "Very positive", "Positive" and "Negative" according to the experience gained during their teaching practicum. The reflections described with the help of such word combinations as "very confident", "very satisfied", "completely sure", "really confident", "feel great satisfaction" belong to a "Very positive" group. The statements containing the phrases like "feel confident", "rather satisfied", "sure", "have positive feelings" that express neutral attitude of pre-service teachers to using ICT, form the group entitled "Positive". The third "Negative" group including the reflections with the description of students' passive attitude to the use of ICT was recognized by means of the following word combinations: "feel nervous", "feel worried", "feel not very calm", "being anxious", "feel embarrassed". A number of excerpts taken from their reflections have been discussed in this part.

Among the 60 pre-service teachers of the specialty "Secondary education", 36 belonging to the group "Very positive"were of the opinion that using ICT in their classes was extremely important because of the demand of time and development of modern education system. They stated that using ICT in class made them feel confident and they were satisfied with their performance. They also added that the course on ICT in Learning and Teaching English they had completed before their practicum was of particular help and certainly one of the best in the curriculum. Among the "very positive" reflections, pre-service teacher №16 stated that "I feel extremely confident and satisfied when I use ICT in classes. Any technical support is very important in explaining a new material to students. I get the desirable result after delivering classes using ICT: a projector, power point presentation, podcasts and blogs". Another positive feedback was given by pre-service teacher №23 who said that "I feel really confident when I can easily explain grammar using ICT'.

Students' curriculum in the specialty "Philology" does not include such a course as ICT in Learning and Teaching English. Consequently, no "very positive" opinions were found among the students of this specialty.

Overall, 55 pre-service teachers of the specialty "Philology" and 23 students of the specialty "Secondary Education" out of 120 respondents had "positive" views on using ICT during their teaching practicum. One of the participants reported that "I feel rather satisfied while using 
different video and audio aids...With the help of all these technologies we have many opportunities to improve the quality of teaching" (Pre-service teacher №4). Another respondent said that "In general I support the idea of using ICT in the teaching process and I feel quite calm with it... The only problem for me is the fear whether the chosen teaching materials (especially videos) correspond to the learners' language level' (Pre-service teacher №15).

Among 120 pre-service teachers of both specialties only 6 gave "negative" opinion on using ICT in their teaching. This can be supported by the following reflection: "I feel worried and very nervous when I use IT in my classes. That is why I use it only at home" (Pre-service teacher №44).

This study also attempted to find out the anxiety-reducing factors during teaching practicum. It is obvious that the general level of anxiety influences greatly the level of anxiety when using ICT. In terms of effective factors, the results revealed that the pre-service teachers who had an ICT course showed a lower level of anxiety in comparison with those who did not. Analysis of the questionnaires has proved that pre-service teachers of the specialty "Secondary Education" are less anxious as they had the ICT in Learning and Teaching English course which provided them with some theoretical background through practice.

A crucial factor for teachers to integrate ICT into their classes is being trained in how to use technology in education. In this regard, the courses in ICT as a part of education program for pre-service teachers play a significant role in training student teachers to integrate technology into education.

Within the framework of 'New Generation School Teacher Project' jointly initiated by the British Council Ukraine and the Ministry of Education and Science Ukraine, National Curriculum for foreign teacher education (Methodology) has been introduced. The overall aim of the project is to improve student-teachers' and newly-qualified teachers' English proficiency and to develop teachers' digital and social media skills. As a result, newlyqualified teachers can integrate ICT in/outside the classroom.

The students of the specialty "Secondary Education"are trained with Information and Communication Technologies (ICT) in Learning and Teaching English course in year four. The main objectives of the course are to make students aware of the advantages and disadvantages of doing activities on a computer as opposed to similar paper-based activities; the criteria for evaluating and selecting online resources for language teaching purposes; the main uses of IWBs and their benefits as opposed to traditional whiteboards. By the end of the course the students are supposed to be able to use different software (e.g. MSWord, PowerPoint) for language learning and teaching purposes; make use of social networking sites, blogs, wikis, etc. in language teaching; evaluate the potential of online audio and video for language teaching purposes; assess possible risks of using the Internet with young learners and develop a set of rules for cyber safety; explore current trends in mobile learning and be able to use mobile phones for teaching and learning.

It is understood from the objectives of the ICT in Learning and Teaching English course that pre-service teachers are expected to be literate in technology and to use the existing technology in teaching-learning process. The course consists of nine interactive sessions dealing with modern learning technologies and their relevance for the educational process, keeping children safe on the Internet, the use of learning platforms for teaching purposes, the notion of a 'flipped' classroom and its benefits, exploration of opportunities offered by mobile devices (e.g. smartphone) in language learning. After the course the students are asked to complete the assignment to develop an activity using ICT, e.g. computer, smart phone, tablet, network hardware and software for primary or secondary learners, then try the activity out with a specified group of learners and justify the use of ICT in writing (maximum 150 words). As the students of the specialty "Secondary Education" have observation and assistance practicum at school once a week, they should also carry out a task to observe at least 3 lessons focusing on the use of learning technologies and note down the purpose of use. The students analyse the use of learning 
technologies and answer the questions that help them understand how effective the use of the learning technology was in general and how it supported the pupils' learning.

\section{CONCLUSIONS AND PROSPECTS FOR FURTHER RESEARCH}

Based on the findings, it is proved that ICT is one of the essential factors reducing anxiety of pre-service teachers in their teaching practicum. Contrastively, the result of this study revealed some different results from those found in the literature where it is stated that ICT causes teachers' anxiety and affects their performance in class [5] - [7]. Speaking specifically, this research may suggest that pre-service teachers should use ICT during their practicum at school to a greater extent to feel more confident.

Some practical recommendations can be given, namely, before conducting teaching experience it is crucial that students take an ICT course, as gaining ICT knowledge and skills can reduce pre-service teachers' anxiety when performing in class. Only under these circumstances, pre-service teachers can effectively conduct teaching by implementing knowledge and skills gained in the ICT course. As the study was restricted to 120 pre-service teachers at two universities and carried out by means of questionnaires and reflections, it must be stated that the data obtained from this research was rather limited.

It is evident that there are other effective factors to reduce teachers' anxiety apart from ICT which can be the subject matter for further research.

\section{REFERENCES (TRANSLATED AND TRANSLITERATED)}

[1] Longman Dictionary of Contemporary English, p. 55, 2003. (in English)

[2] T. Scovel,"The Effect of Affecton Foreign Language Learning: A Review of the Anxiety Research.”Language Learning, vol. 28, pp. 129-142, 1978.(in English)

[3] R. Ellis, The study of second language acquisition. Oxford: Oxford University Press, 1994.(in English)

[4] E. K. Horwitz, M. B. Horwitz and J. Cope,"Foreign language classroom anxiety."Modern Language Journal,vol. 70,pp.125-132, 1986. (in English)

[5] D. Choy, F. L. Wong and P. Gao, "Student teachers' intentions and actions on integrating technology into their classrooms during student teaching: A Singapore study."Journal of Research on Technology in Education, vol.42, pp.175-195, 2009. (in English)

[6] L. Rosen and M. Weil, "Computer Availability, Computer Experience and Technophobia among Public School Teachers." Computers in Human Behaviour, vol. 11, pp. 9-31, 1995. (in English)

[7] M. Salanova, S. Llorens and E. Cifre, "The Dark Side ofTechnologies: Technostress among Users of Informationand Communication Technologies.” International Journal of Psychology, vol. 48, pp. 422436,2013.(in English)

[8] S. E. Chang, "Computer Anxiety and Perception of Task Complexity in Learning Programming-Related Skills."Computers in Human Behaviour, vol.21, pp. 713-728, 2005. (in English)

[9] R. L. Oxford, “Anxiety and the language learner: New insight.”Language Learning, vol. 39, no. 2 , 1989. (in English)

[10] M. Randall and B. Thornton, Advising and Supporting Teachers. Cambridge University press, 2001, pp. 99-100. (in English)

[11] P. R. Albion, J. Tondeur, A. Forkosh-Baruch and J. Peeraer,"Teachers' professional development for ICT integration: towards a reciprocal relationship between research and practice."Education and Information Technologies, vol. 20(4), pp. 655-673, 2015. (in English)

[12] D. L. Lowther, F. A. Inan, J. D. Strahl and S. M. Ross, "Does technology integration work when key barriers are removed?" Educational Media International, vol. 45, pp.195-213, 2008. (in English)

[13] T. V. Weertand A. Tatnall, "Information and Communication Technologies and Real-Life Learning:New Education for the New Knowledge Society”, Springer, New York, 2005. (in English)

[14] J. J. Castro Sánchez and E. C. Alemán, "Teachers' opinion survey on the use of ICT tools to support attendance-based teaching." Computers and Education, vol. 56,pp. 911-915, 2011. (in English)

[15] J. Samuel Gnanamuthu, R. Krishnakumar, "Anxiety of B.Ed. teacher trainees' towards ICT”,InternationalJournal of Applied Research, vol. 1(6), pp. 59-62, 2015. (in English) 
[16] A. P. Rovai and M. Childress, "Explaining and Predicting Resistance to Computer Anxiety Reduction among Teacher Education Students."Journal of Research on Technology in Education, vol. 35, pp. 226235, 2002. (in English)

[17] Ö. Ursavaş and H. Karal,“Assessing pre-service teachers' computer phobia levels in terms of gender and experience, Turkish sample."International Journal of Behavioral, Cognitive, Educational and Psychological Sciences, vol. 1(1), 2009. (in English)

[18] D. Tüfekçi-Can, "Pre-service teachers'foreign language teaching anxiety during teaching practicum."International Online Journal of Education and Teaching (IOJET), [Online]. Available: http://www.iojet.org/index.php/IOJET/article/view/420,vol. 5(3), pp. 579-595, 2018. Accessed on: March 7, 2019.(in English)

[19] G. Sang, M. Valcke, J. Van Braak andJ. Tondeur, "Student teachers' thinking processes and ICT integration: Predictors of prospective teaching behaviors with educational technology."Computers \&Education, vol. 54(1), pp. 103-112, 2010. (in English)

[20] D. D. Agyei andJ. M. Voogt, "Exploring the potential of the will, skill, tool model in Ghana: predicting prospective and practicing teachers' use of technology."Computers \& Education, vol. 56, pp. 91-100, 2011. (in English)

[21] L. Gill,B. Dalgarno and L. Carlson, "How Does Pre-Service Teacher Preparedness to Use ICTs forLearning and Teaching Develop Through Their Degree Program?"Australian Journal of Teacher Education, vol. 40(1), 2015. (in English)

[22] D. O. Tum, "Feelings of language anxiety amongst non-native student teachers." Procedia: Social and Behavioral Sciences, vol. 47, pp. 2055-2059, 2012. (in English)

[23] E. K. Horwitz, "Even teachers get the blues: Recognizing and alleviating language teachers' feelings of foreign language anxiety." Foreign Language Annals, vol. 29(3), pp. 365-372,1996. (in English)

[24] G. Russell andG. Bradley, "Teachers' computer anxiety: Implications for professional development."Education and Information Technologies, vol. 2, pp.17-30, 1997. (in English)

[25] V. I. Bobrytska and S. M. Protska, "Formation of the professional competencies in the future teachers of language and literature through the tools of the computer-based technologies."Information technologiesandteaching tools, [Online]. Available: http://journal.iitta.gov.ua/index.php/itlt/issue/view/87/showToc, № 2 (58), pp. 59-66, 2017. Accessed on: March 15, 2019.(in Ukrainian)

[26] T. Teo, "Factors influencing teachers' intention to use technology: model development and test." Computers \& Education, vol. 57, pp. 2432-2440, 2011. (in English)

[27] A. Birch and V. Irvine, "Pre-service teachers' acceptance of ICT integration in the classroom: Applying the UTAUT model." Educational Media International, vol. 46, pp. 295-315, 2009. (in English)

[28] L. R. Gay, Educational research competencies for analysis and application (3rd ed.). London: Merrill Publishing Company. 1987. (in English)

[29] J. Taylor, "A personality scale of manifest anxiety." The Journal of Abnormal and Social Psychology, vol. 48(2), pp. 285-290, 1953. (in English)

[30] M. D. Gall, J. P. Gall and W. R. Borg, Educational research: an introduction (7th ed.). Allyn and Bacon, Boston, MA. 2003. (in English)

Text of the article was accepted by Editorial Team 26.04.19

\title{
ІКТ ЯК ЗАСІБ ЗНИЖЕННЯ РІВНЯ ТРИВОЖНОСТІ МАЙБУТНІХ УЧИТЕЛІВ ІНОЗЕМНОЇ МОВИ ПІД ЧАС ПЕДАГОГІЧНОЇ ПРАКТИКИ
}

\author{
Троценко Ольга \\ кандидат педагогічних наук, доцент кафедри англійської філології факультету іноземних мов \\ Прикарпатський національний університет імені Василя Стефаника, м. Івано-Франківськ, Україна \\ ORCID ID 0000-0002-5023-0563 \\ trocolya@gmail.com \\ Білик Ольга \\ кандидат філологічних наук, доцент кафедри англійської філології факультету іноземних мов \\ Прикарпатський національний університет імені Василя Стефаника, м. Івано-Франківськ, Україна \\ ORCID ID 0000-0002-3973-0700 \\ noiproks2014@ukr.net
}




\title{
Пилячик Наталія
}

кандидат філологічних наук, доцент кафедри англійської філології факультету іноземних мов Прикарпатський національний університет імені Василя Стефаника, м. Івано-Франківськ, Україна ORCID ID 0000-0002-0642-6745

natapiliachik@gmail.com

\begin{abstract}
Анотація. Майбутні вчителі, які виросли в добу сучасних інформаційно-комунікаційних технологій (ІКТ), є технічно обізнаними. Саме тому вважається, що такі спеціалісти мають на високому рівні і з легкістю використовувати цифрові технології в процесі навчання та викладання. У статті розглянуто ІКТ як фактор, який впливає на рівень тривожності майбутніх учителів. Дослідження також має на меті визначити роль IКТ у зниженні рівня тривожності майбутніх учителів іноземної мови в процесі їхньої професійної діяльності. Вважається, що тривожність має значний вплив на життєдіяльність особистості, а особливо на процес навчання та викладання. Дослідження проводилось за допомогою методу анкетування. Спочатку визначався рівень тривожності майбутніх учителів іноземної мови у різних повсякденних ситуаціях. Друге анкетування, розроблене авторами, стосувалось соціально-психологічного експерименту та мало на меті визначити вплив використання IКТ на рівень тривожності майбутніх учителів іноземної мови в процесі їх педагогічної практики. У дослідженні взяли участь 120 студентів Прикарпатського національного університету імені Василя Стефаника та Уманського державного педагогічного університету імені Павла Тичини, які пройшли свою педагогічну практику як частину навчальної програми на факультеті іноземних мов. Дані, отримані в процесі дослідження, були розподілені на дві основні категорії: загальний рівень тривожності студентів та рівень тривожності в процесі використання ІКТ на заняттях з англійської мови. Результати анкетування були погруповані в категорії «Дуже позитивно», «Позитивно» та «Негативно», базуючись на досвіді, отриманому майбутніми вчителями іноземної мови впродовж їхньої педагогічної практики. Було досліджено, що використання ІКТ значною мірою знижує рівень тривожності студентів. Результати експерименту показали, що майбутні вчителі, які завершили передбачений навчальною програмою курс, який стосується особливостей використання ІКТ у процесі навчання, почувались більш впевнено під час проведення уроків іноземної мови, та їхній рівень тривожності був значно нижчий.
\end{abstract}

Ключові слова: ІКТ; майбутні вчителі; зниження рівня тривожності; педагогічна практика.

\section{ИКТ КАК СРЕДСТВО СНИЖЕНИЯ УРОВНЯ ТРЕВОЖНОСТИ БУДУЩИХ УЧИТЕЛЕЙ ИНОСТРАННОГО ЯЗЫКА ВО ВРЕМЯ ПЕДАГОГИЧЕСКОЙ ПРАКТИКИ}

\section{Троценко Ольга}

кандидат педагогических наук, доцент кафедры английской филологии факультета иностранных языков Прикарпатский национальный университет имени Василия Стефаника, г. Ивано-Франковск, Украина ORCID ID 0000-0002-5023-0563

trocolya@gmail.com

\section{Билык Ольга}

кандидат филологических наук, доцент кафедры английской филологии факультета иностранных языков Прикарпатский национальный университет имени Василия Стефаника, г. Ивано-Франковск, Украина ORCID ID 0000-0002-3973-0700 noiproks2014@ukr.net

\section{Пилячик Наталия}

кандидат филологических наук, доцент кафедры английской филологии факультета иностранных языков Прикарпатский национальный университет имени Василия Стефаника, г. Ивано-Франковск, Украина ORCID ID 0000-0002-0642-6745 natapiliachik@gmail.com

Аннотация. Будущие преподаватели, которые выросли в эпоху информационнокоммуникационных технологий (ИКТ), считаются компьютерно грамотными. В этом случае они должны быть опытными в использовании ИКТ для обучения и преподавания. В этой 
статье исследуются ИКТ как фактор, влияющий на уровень тревожности будущих учителей. Кроме того, статья нацелена на определение роли ИКТ в снижении уровня тревожности будущих преподавателей иностранных языков во время их педагогической практики. Считается, что тревожность оказывает сильное влияние на повседневную жизнь людей и, в частности, на процесс обучения и преподавания. Инструментами исследования были закрытые анкеты, заполненные респондентами. Первая из них использовалась для измерения шкалы тревожности будущих учителей в различных ситуациях повседневной жизни. Вторая анкета была основана на социально-психологическом эксперименте авторов, направленном на выявление влияния ИКТ на тревожность будущих учителей во время педагогической практики. В исследовании приняли участие 120 студентов - будущих преподавателей английского языка, которые обучаются в Прикарпатском национальном университете имени Василия Стефаника и в Уманском государственном педагогическом университете имени Павла Тичины, которые проходят педагогическую практику как часть учебной программы факультетов иностранных языков. Данные, полученные из анкет, были сгруппированы в две основные категории: общий уровень тревожности студентов и тревожность, связанная с использованием ИКТ в преподавании английского языка. Последняя была разделена на группы «Очень позитивно», «Позитивно» и «Негативно» на основе опыта будущих учителей, полученного во время их преподавательской практики. Было установлено, что использование ИКТ влияет положительно на студентов и в значительной степени снижает уровень тревожности учителей. Результаты исследования показали, что студенты, проходившие курс по ИКТ в рамках своей учебной программы, чувствовали себя более уверенно при проведении преподавательской деятельности, и их уровень тревожности снижался при использовании ИКТ.

Ключевые слова: ИКТ; будущие учителя; снижение уровня тревожности; педагогическая практика.

\section{(cc) BY-NC-SA}

This work is licensed under Creative Commons Attribution-NonCommercial-ShareAlike 4.0 International License. 